\title{
Characterisation of the IGF system in a primary adult human skeletal muscle cell model, and comparison of the effects of insulin and IGF-I on protein metabolism
}

\author{
A L Crown ${ }^{1}$, X L He, J M P Holly, S L Lightman ${ }^{1}$ \\ and $\mathbf{C}$ E H Stewart
}

Department of Surgery, University of Bristol, Bristol Royal Infirmary, Marlborough Street, Bristol BS2 8HW, UK

${ }^{1}$ Department of Medicine, University of Bristol, Bristol Royal Infirmary, Marlborough Street, Bristol BS2 8HW, UK

(Requests for offprints should be addressed to C E H Stewart, University of Bristol, Department of Surgery, Bristol Royal Infirmary, Bristol BS2 8HW, UK; Email: c.stewart-paton@bristol.ac.uk)

\begin{abstract}
In an attempt to address the complex and clinically challenging question of the causes of muscle wasting in patients with cachexia, we have developed a primary adult human skeletal muscle cell model. The cultured cells were characterised by immunocytochemistry using antibodies to the myofibrillar protein constituents desmin and titin. Myotube formation was confirmed biochemically by a fourfold increase in the activity of the muscle-specific enzyme creatinine kinase, and myoblast withdrawal from the cell cycle, which is essential for terminal differentiation, was associated with progressive retinoblastoma protein dephosphorylation. Having successfully confirmed the phenotype of these adult human muscle cells, we assessed their interaction with the insulin-like growth factor (IGF) system. IGF-I is known to stimulate myoblast survival, proliferation and differentiation in cell lines, and, like insulin, is a potent anabolic agent in the regulation of protein metabolism. We have shown that IGF-I stimulated both replication and differentiation of myoblasts, whilst fibroblast growth factor-2 stimulated replication but inhibited differentiation. Examining the IGF system during the
\end{abstract}

process of terminal differentiation, we found that both myoblasts and myotubes expressed insulin, IGF-I and insulin-IGF-I hybrid receptors, with the levels of all three receptor types increasing on differentiation. The cells also produced a wide range of IGF binding proteins (IGFBPs) including IGFBP-2, IGFBP-4 and abundant IGFBP-3, which has not been shown to be produced by any other skeletal muscle cell line examined to date. Both insulin and IGF-I had anabolic effects on myotube protein metabolism at physiological concentrations. Insulin was more potent than IGF-I: use of the IGF analogue long $\mathrm{R}^{3}$ IGF-I demonstrated that the effects of exogenous IGF-I on protein metabolism were not affected by the high levels of endogenous IGFBP production. In summary, we have developed and characterised a clinically relevant in vitro model with which to address the aetiology of muscle wasting associated with chronic catabolic conditions, and we anticipate that future work will enable the development of novel, effective therapeutic interventions. Journal of Endocrinology (2000) 167, 403-415

\section{Introduction}

Cachexia is associated with many chronic severe illnesses and is characterised by anorexia, weight loss, and an altered metabolism with increased energy expenditure (Calman 1982). There is an impaired ability to conserve lean body mass which results in muscle wasting (Wilmore 1991), affecting respiratory muscles, mobility and performance status. Even small amounts of weight loss (less than 5\%) significantly worsen the prognosis of patients with cancer (DeWys et al. 1980). Cachexia has been described as 'among the most visible and devastating consequences of several human diseases' (Nabel \& Grunfeld 1996) yet at present no effective treatment is available.
We and others have demonstrated that the insulin-like growth factors (IGFs) are unique in their ability to stimulate myoblast survival and proliferation, as well as differentiation (Florini et al. 1995, Stewart \& Rotwein 1996). Supporting these in vitro data, the relevance of the IGF system has been demonstrated in vivo, where IGF-I, IGF-II and IGF-I receptor knockout studies result in neonatal lethality primarily as a consequence of skeletal muscle hypoplasia (Liu et al. 1993, Stewart \& Rotwein 1996). Although there is much in vitro evidence to support the anabolic roles of insulin and IGF-I in regulating skeletal muscle protein metabolism, many of these studies have used immortalised skeletal muscle cell lines originating from the rat (L6) or mouse (C2) (Roeder et al. 1988), 
or, where primary cultures have been used, they have been derived from fetal tissue (Hill et al. 1986, Frost et al. 1997, Harper et al. 1987). Additionally, many of the above experiments have been performed on myoblasts rather than the more physiologically relevant myotubes (Hill et al. 1986, Frost et al. 1997). While the role of the IGF binding proteins (IGFBPs) in modulating the metabolic responses of skeletal muscle to IGF-I has not been addressed, their release and relevance has been demonstrated in murine $\mathrm{C} 2$ myoblasts, where IGFBP-5 reduced differentiation whilst maintaining myoblast cell survival (James et al. 1996).

IGF-I and insulin have been used in attempts to treat cachexia in human disease (Wolf et al. 1992, Lieberman et al. 1994, Lee et al. 1996) and in animal models (Douglas et al. 1991, $\mathrm{Ng}$ et al. 1992, Tomas et al. 1994), but the results of such studies have been variable, re-emphasising the need for an improved understanding of the pathophysiology of muscle wasting in order to develop better therapeutic interventions. In order to achieve this end, an in vitro model which is relevant to the study of patients with cachexia is required. We therefore developed a primary adult human skeletal muscle cell culture system, and characterised the cells with regard to their morphological and biochemical parameters of differentiation. Since the IGFs appear to be critical for the formation of multinucleate myotubes, we examined the IGF system during the process of terminal differentiation. Results reported here demonstrate that the cells express insulin, IGF-I and insulin-IGF-I hybrid receptors and produce a wide range of IGFBPs, surprisingly including abundant IGFBP-3. Having characterised the system, we confirmed the functionality of the cells by demonstrating anabolic effects of insulin and IGF-I on protein metabolism, with insulin being more potent at physiological concentrations. Thus we have developed and characterised a sophisticated in vitro model with which to address the complex problem of muscle wasting associated with chronic catabolic conditions.

\section{Materials and Methods}

\section{Subjects}

Perioperative skeletal muscle biopsies were taken from the anterior abdominal wall of women between 18 and 60 years of age undergoing elective gynaecological operations for non-malignant conditions. Those with known metabolic or endocrine disease were excluded. Cells derived from 30 women with a mean age of 43.3 years (standard deviation 8.0 years) were used in these studies. A smaller number of biopsies were also taken from the anterior abdominal wall of subjects undergoing upper gastrointestinal operations. The study was approved by the local Ethical Committee, and all subjects gave written, informed consent.

\section{Media}

All chemicals and media are from Sigma (Poole, Dorset, UK) unless otherwise stated. The skeletal muscle growth medium (GM) is a modification of that of Ham et al. (1988): MCDB-131 with L-glutamine, $50 \mathrm{IU} / \mathrm{ml}$ penicillin, $5 \mu \mathrm{g} / \mathrm{ml}$ streptomycin, $2.5 \mu \mathrm{g} / \mathrm{ml}$ amphotericin $\mathrm{B}$, $0.4 \mu \mathrm{g} / \mathrm{ml}$ dexamethasone, $0.5 \mathrm{mg} / \mathrm{ml}$ bovine serum albumin (BSA), $0.5 \mathrm{mg} / \mathrm{ml}$ fetuin, and $10 \%$ fetal calf serum (FCS) (GIBCO, Paisley, UK). Initially, $50 \mu \mathrm{g} / \mathrm{ml}$ insulin (Novo Nordisk, Crawley, West Sussex, UK) was included in the GM, as suggested by Ham et al. (1988); we subsequently found that cells grew equally well in the absence of insulin. Skeletal muscle fusion medium (FM) consisted of minimum essential medium (MEM)-alpha modification with $50 \mathrm{IU} / \mathrm{ml}$ penicillin, $5 \mu \mathrm{g} / \mathrm{ml}$ streptomycin, 1\% L-glutamine and 2\% FCS (GIBCO). Fibroblast growth medium was Dulbecco's modified Eagle's medium (DMEM) with Glutamax, with $50 \mathrm{IU} / \mathrm{ml}$ penicillin, $5 \mu \mathrm{g} / \mathrm{ml}$ streptomycin, $2.5 \mu \mathrm{g} / \mathrm{ml}$ amphotericin B and $10 \%$ FCS. For serum-free medium (SFM), the FCS was omitted from the skeletal muscle FM/fibroblast GM, and $0 \cdot 1 \%$ BSA was added.

\section{Isolation of primary adult human myoblasts}

Primary skeletal muscle cell cultures were derived according to a modified method of Blau and Webster (1981). Briefly, biopsies were dissected in phosphate-buffered saline (PBS) to remove all visible fat and connective tissue, and were then chopped finely $\left(1 \mathrm{~mm}^{3}\right.$ pieces), prior to being digested in trypsin/EDTA (T/E solution at final concentrations of $0.05 \%$ trypsin and $0.02 \%$ EDTA in PBS) for $15 \mathrm{~min}$. The supernatant was removed and mixed with FCS (GIBCO), centrifuged at 1300 r.p.m. for $5 \mathrm{~min}$ and the pellet resuspended in skeletal muscle GM. This process was repeated an additional three times. The cell suspensions from each $\mathrm{T} / \mathrm{E}$ digestion were pooled and plated in Nunclon flasks pre-coated with $0 \cdot 2 \%$ gelatin type B. Cells were allowed to settle for up to $72 \mathrm{~h}$ before the first medium change, and were passaged upon attaining 80$90 \%$ confluency. Cells at passages 3-5 were used for all experiments. When confluent, experimental cells were washed twice with PBS prior to addition of FM. All experiments were carried out following 7 days in FM, unless otherwise stated.

\section{Human fetal myoblasts}

Human fetal myoblasts derived from a 22-week-old fetus were purchased from Clonetics (Wokingham, Berks, UK).

\section{Primary human fibroblasts}

Primary adult human skin fibroblasts (which were a kind gift from Dr Jane Samson, Bristol Royal Infirmary) were derived from epidermal biopsies. 


\section{Characterisation of primary human myoblasts}

Immunocytochemical characterisation was carried out on cells grown on glass coverslips and on cytospins of cell suspensions. Mouse monoclonal antibodies to the myofibrillar protein constituents desmin (Dako, Ely, Cambs, UK) and titin (Novocastra, Euro-Path Ltd, Bude, Cornwall, UK) were used at dilutions of 1:100, followed by specific secondary antibodies. Nuclei were counterstained with haematoxylin for clarity, in order that the ratio of positively staining myoblasts to negatively staining fibroblasts could be easily quantitated. In addition to the cellular morphology and immunocytochemistry, differentiation was also characterised biochemically by measuring the activity of the muscle-specific enzyme creatinine kinase (CK) in Tris-MES-Triton cell lysates $(50 \mathrm{mM}$ Tris-MES $\mathrm{pH} 7 \cdot 8$ with $1 \%$ Triton-X 100), using the 'CK-10' kit (Sigma). Samples were stored at $-80^{\circ} \mathrm{C}$ and assayed within 14 days of collection. Enzymatic activity was normalised to total protein content, as determined by the bicinchonic acid (BCA) protein assay according to the manufacturer's instructions (Pierce, Chester, UK).

Cell cycle arrest was determined by assessing the retinoblastoma protein $(\mathrm{Rb})$ status of myoblasts and myotubes. Cells were lysed (10 mM Tris- $\mathrm{HCl} \mathrm{pH}$ 7·6, $5 \mathrm{mM}$ EDTA, $50 \mathrm{mM} \mathrm{NaCl}, 30 \mathrm{mM}$ Na pyrophosphate, $50 \mathrm{mM}$ $\mathrm{NaF}, 100 \mu \mathrm{M}$ Na orthovanadate, $1 \%$ Triton-X 100, with $10 \mu \mathrm{l}$ phenylmethylsulphonylfluoride (PMSF) solution/ml (1 $\mathrm{mg}$ PMSF in $0.57 \mathrm{ml}$ ethanol) added immediately before use), and the lysates were subjected to 6\% SDS polyacrylamide gel electrophoresis (PAGE) under denaturing, reducing conditions. Following electro-transfer to nitrocellulose ('Hybond-C' membrane, Amersham Life Science, Little Chalfont, Bucks, UK), non-specific binding sites were blocked in 5\% non-fat dried milk for at least one hour at room temperature. Blots were then incubated with a 1:500 dilution of phospho-specific goat anti-Rb antibody (Santa Cruz Biotechnology, Santa Cruz, CA, USA). After incubation with horseradish peroxidase conjugated anti-goat immunoglobulin, proteins were detected by enhanced chemiluminescence (ECL detection reagents, Amersham Life Science) followed by autoradiography. All experiments described were performed following 7 days in FM with or without IGF-I or fibroblast growth factor-2 (FGF-2) as positive and negative differentiation controls respectively (Florini et al. 1995).

\section{IGF-I and insulin receptor status}

To assess the IGF-I and insulin receptor status, cells were lysed (as detailed above) and the protein concentration determined by BCA assay according to the manufacturer's instructions. Samples were boiled for $5 \mathrm{~min}$ in Laemmli reducing sample buffer (Sigma) and loaded according to their protein content on an $8 \%$ polyacrylamide gel.

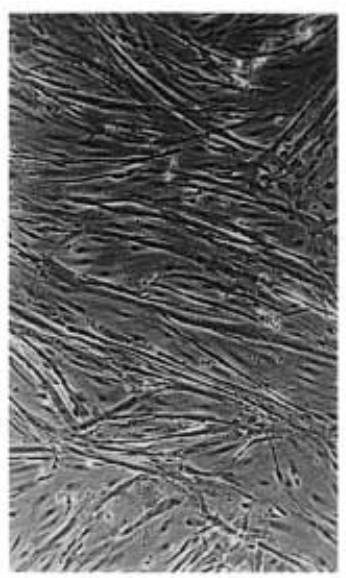

4 days in fusion medium

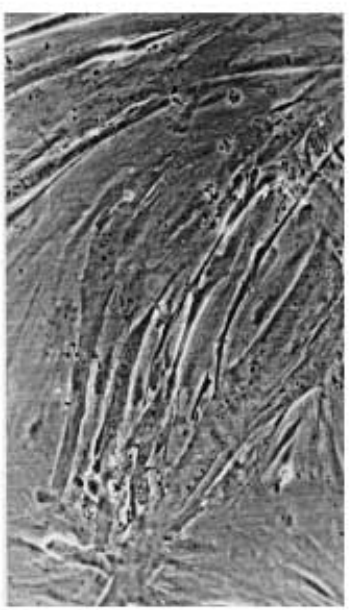

9 days in fusion medium

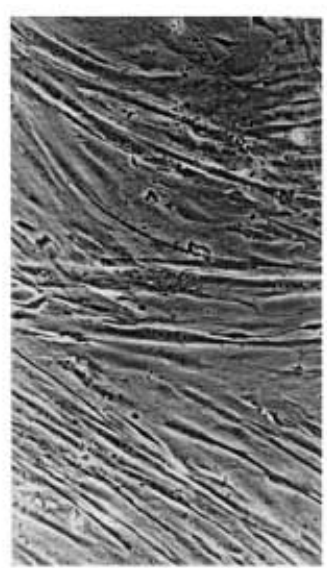

6 days in fusion medium

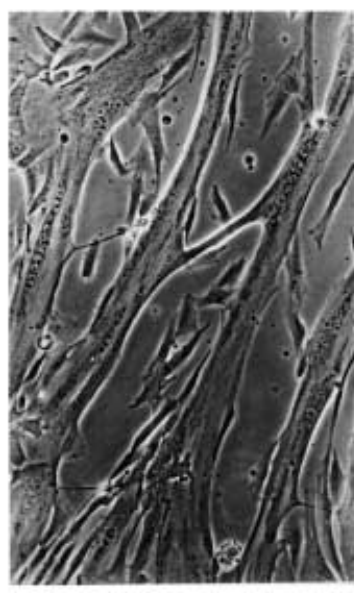

10 days in fusion medium
Figure 1 Phase contrast light microscopy of primary human myoblasts and myotubes showing progressive differentiation in fusion medium (magnification $\times 20$ ).

Following electrophoresis, the proteins were electrotransferred onto a nitrocellulose membrane. Immunoblotting was carried out using primary antibodies to the insulin or the IGF-I receptor $\beta$-subunits (Santa Cruz Biotechnology) at dilutions of 1:500. Following incubation with secondary antibodies, proteins were detected by ECL followed by autoradiography (X-Omat LS, Kodak, Sigma).

For analysis of the insulin-IGF-I hybrid receptor status, $200 \mu \mathrm{g}$ total cell lysates isolated as above were immunoprecipitated using the anti-IGF-I receptor antibody conjugated to protein A agarose beads (Calbiochem, Nottingham, UK). After mixing for $3 \mathrm{~h}$ at $4{ }^{\circ} \mathrm{C}$, samples were boiled in Laemmli buffer and subjected to SDS PAGE followed by electro-transfer. The nitrocellulose membrane was then immunoblotted using the anti-insulin receptor antibody as above. 

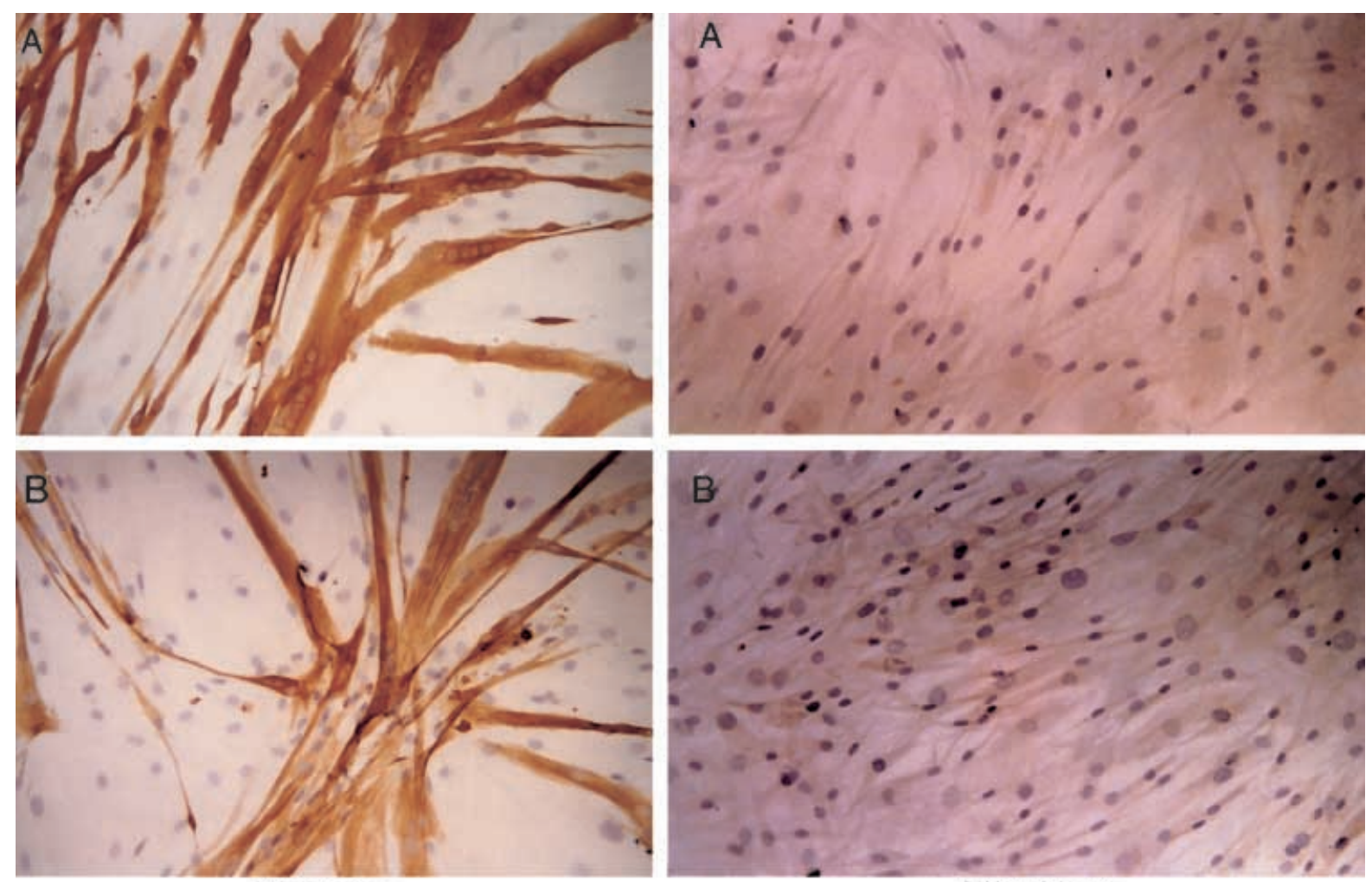

Myotubes

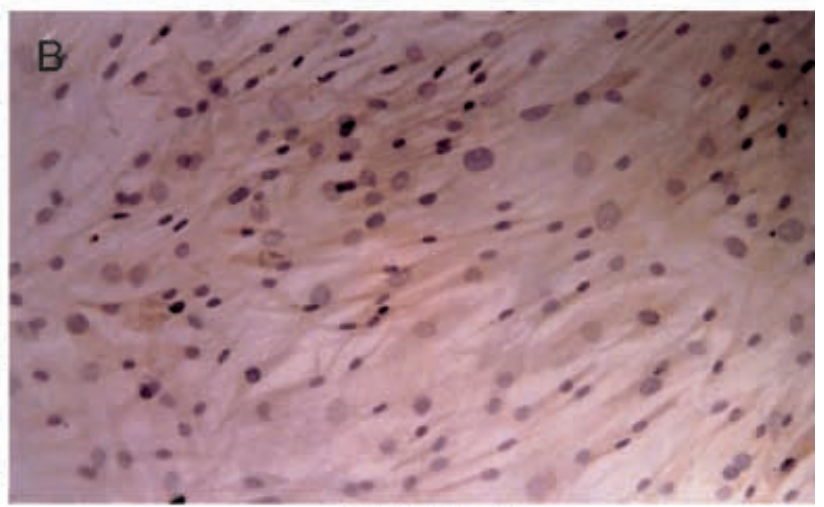

Fibroblasts

Figure 2 Immunocytochemical characterisation of myotube cultures and negative staining of fibroblast cultures using (A) antidesmin and (B) anti-titin antibodies (magnification $\times 20$ ).

\section{IGFBP profiles}

IGF binding protein (IGFBP) profiles in conditioned media were examined by SDS PAGE followed by Western ligand and immunoblotting. Samples were denatured by boiling for $5 \mathrm{~min}$ in non-reducing sample buffer, then separated by $12.5 \%$ SDS PAGE and blotted onto a nitrocellulose membrane. The membrane was blocked successively in solutions containing $0 \cdot 8 \%$ Tris $-\mathrm{HCl} \mathrm{pH} 7 \cdot 4$ with $0 \cdot 05 \%$ Nonidet $\mathrm{P} 40$ (30 $\mathrm{min}), 3 \%$ bovine serum albumin $(90 \mathrm{~min}$ ) and $0 \cdot 8 \% \mathrm{NaCl}$ and $0 \cdot 2 \%$ Tween 20 (20 $\mathrm{min})$, then probed using ${ }^{125} \mathrm{I}-\mathrm{IGF}-\mathrm{I}$ and ${ }^{125} \mathrm{I}$-IGF-II, and, after washing, was exposed to autoradiographic film (Coulson et al. 1991). Immunoblotting was subsequently carried out using an in-house anti-IGFBP-3 rabbit polyclonal antibody (1:15 000; Cwyfan Hughes et al. 1995), or an IGFBP-2 antibody (1:2000, TCS Biologicals Ltd, Buckingham, UK), or an IGFBP-4 antibody (1:1000, TCS Biologicals Ltd), followed by ECL.

\section{Radioimmunoassays for IGF-I, IGF-II and IGFBP-3}

The IGF-I, IGF-II and IGFBP-3 concentrations were measured by in-house radioimmunoassays (RIA). IGF-I and -II were measured after formic acid-acetone extrac- tion. For the IGF-I RIA, cold IGF-II was added to decrease interference by binding proteins, and vice versa. The anti-IGF-I monoclonal antibody (BPL-M23, from Blood Products Ltd, Oxford Biotechnologies, Kidlington, Oxford, UK) was used at a final dilution of 1:20 000. The anti-IGF-II monoclonal antibody W5D2 (a gift from Prof. Anne White, Manchester, UK) was used at a final dilution of 1:250 000. The interassay percentage coefficient of variation $(\% \mathrm{cv})$ was $6.2 \%$ for IGF-I and $12.9 \%$ for IGF-II. IGFBP-3 was measured using the in-house antiserum (Cwyfan Hughes et al. 1995) at a final dilution of 1:20 000 (interassay $\% \mathrm{cv} 5 \cdot 1$ ).

All of the methods used to characterise the myoblasts, their IGF-I and insulin receptor status, IGFBP profiles, and IGF-I and -II production were repeated a minimum of three times. Figures 1-6 are representative of the results obtained.

Growth factor effects on myotube protein synthesis and degradation

Protein synthesis and degradation were assessed using methods based on those described by Harper et al. (1987) and Roe et al. (1989). Briefly, responses to insulin (0, 0.5, 


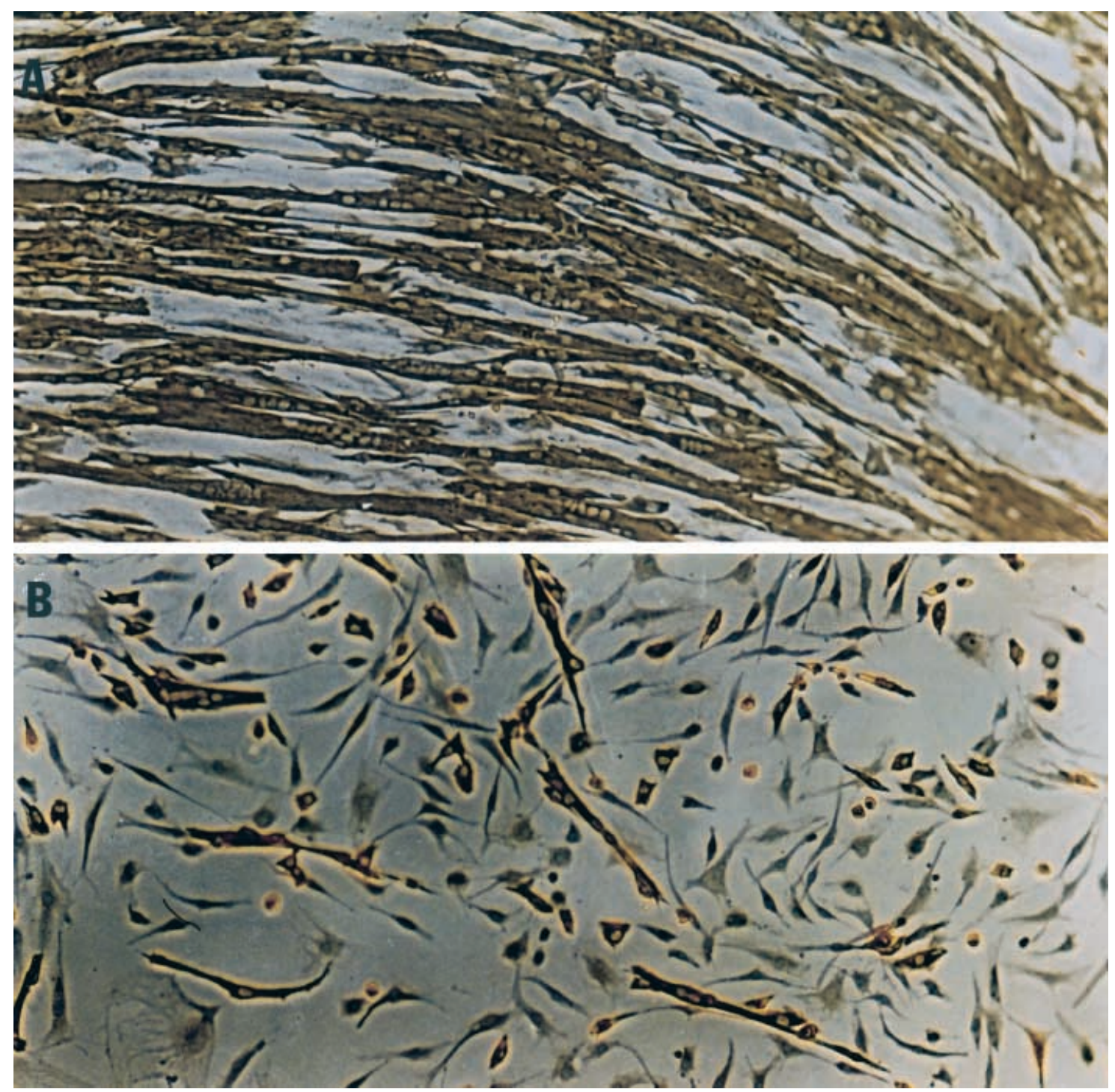

Figure 3 Desmin staining of muscle cells (magnification $\times 20$ ) after 7 days in differentiation medium showing stimulation of myoblast differentiation by IGF-I (A) and inhibition by FGF (B).

$2 \cdot 5,5,50$ and $100 \mathrm{ng} / \mathrm{ml})$ or IGF-I $(0,0 \cdot 75,7 \cdot 5,75,150$ and $300 \mathrm{ng} / \mathrm{ml}$ ) were measured in myotubes. Long $\mathrm{R}^{3}$ IGF-I (LR ${ }^{3}$ IGF-I ) was used to investigate the potential role of endogenously produced IGFBPs in modulating the response of the myotubes to IGF-I. Growth factors were prepared in serum-free medium immediately prior to use. L- $\left[3,5-{ }^{3} \mathrm{H}\right]$ Tyrosine $(0 \cdot 37 \mathrm{MBq}$; Amersham Life Science) in SFM or FM was added to the wells as described below. Muscle cells were grown to confluence and allowed to fuse for 7 days as described. Fibroblasts were used as a control. To assess synthesis, after two washes with PBS, the cells were incubated in SFM for $1 \mathrm{~h}$ before being dosed with peptide and tritiated tyrosine. After a 6-h incubation, (tyrosine is not metabolised to any detectable extent over $72 \mathrm{~h}$ (Roe et al. 1989)), the media were discarded and all wells washed twice with PBS, followed by two washes with cold 5\% trichloroacetic acid (TCA). Sodium hydroxide $(0.5 \mathrm{M})$ was added to each well for $2 \mathrm{~h}$ at $37^{\circ} \mathrm{C}$ to solubilise the cells. The protein concentration in the lysates was measured using the BCA protein assay. Protein synthesis was expressed as counts per minute tritiated tyrosine incorporated into cells over $6 \mathrm{~h}$ (counted using a Beckman LS 6500 Multipurpose Scintillation Counter) per mg protein. To determine protein degradation, for the final $48 \mathrm{~h}$ of the 7-day fusion period, the FM in the labelled wells was changed to include 0.37 $\mathrm{MBq}$ tritiated tyrosine per $\mathrm{ml}$. After labelling, the cells were washed twice with PBS then incubated in SFM for 


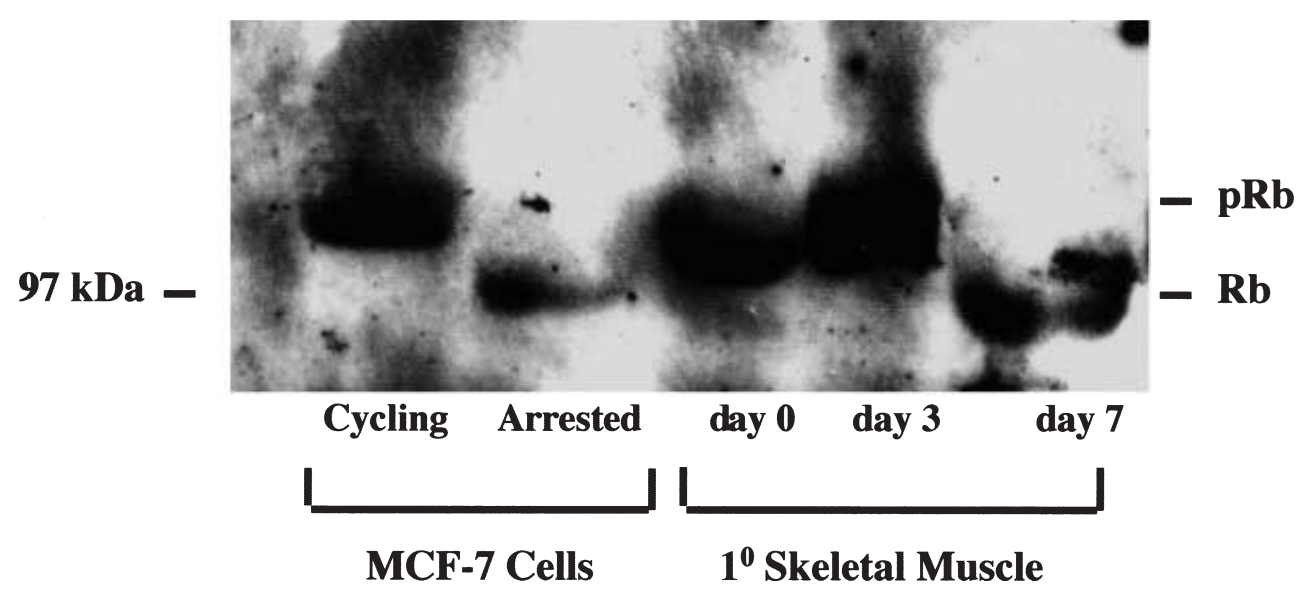

Figure $4 \mathrm{Rb}$ dephosphorylation of muscle cells during 7 days in fusion medium. MCF-7 cell lysates are included as controls for phosphorylated $(\mathrm{pRb})$ and non-phosphorylated Rb.

$1 \mathrm{~h}$ before being dosed with IGF-I or insulin for $24 \mathrm{~h}$. The media were collected and the wells were washed with cold PBS then cold 5\% TCA; all the washings were collected and pooled with the harvested media. Ten percent TCA was added to each sample to bring its final concentration to $5 \%$. Harvested samples were placed on ice for $20 \mathrm{~min}$ prior to centrifugation. The supernatants, acid precipitates and cell monolayers were all solubilised in $0.5 \mathrm{M} \mathrm{NaOH}$. Protein degradation was expressed as follows: \% protein degraded over $24 \mathrm{~h}=100 \% \times$ radioactivity of medium amino acids/(radioactivity of medium amino acids + radioactivity of medium protein + radioactivity of cell protein). Each experiment was performed at least 3 times with wells in triplicate. In each experiment, a fourth unlabelled well was dosed as described, but in the absence of $\left[{ }^{3} \mathrm{H}\right]$ tyrosine. CK activity of the cell lysates was measured in the unlabelled fourth wells, and the conditioned media from these wells was used to analyse IGF binding protein secretion.

\section{Results}

\section{Characterisation of primary skeletal muscle cultures}

Myoblast and myotube cultures were visualised by phase contrast light microscopy ( $\times 20$ magnification). Although fibroblasts and myoblasts could not be thus distinguished, the progressive lining up and elongation of the myoblasts in FM and fusion to form multinucleate myotubes could be seen, as illustrated in Fig. 1. The cells were subsequently positively characterised by immunocytochemistry of the myotube cultures using desmin and titin (Fig. 2). Myotubes stain positively for both desmin and titin, whilst proliferating myoblasts stain positively for desmin in only 95\% of cells (van der Ven et al. 1992). The fibroblast cultures did not stain with either desmin or titin (Fig. 2).
To substantiate these data, cells were cultured with IGF-I or FGF. Figure 3 illustrates the stimulation of myoblast differentiation by IGF-I and the inhibition of differentiation by FGF. Desmin staining of cytospins of myoblast cell suspensions showed that there was a mean of $97.6 \%$ muscle cells and $2 \cdot 4 \%$ fibroblasts (standard deviation $2 \cdot 76$ ). In vivo, non-myogenic cells represent a substantial proportion (25-40\%) of the nuclei of mature muscle (Roe et al. 1989), suggesting that these cultures are enriched for myogenic cells.

Morphological differentiation into myotubes was accompanied by a fourfold increase in biochemical differentiation as assessed by measuring the activity of the muscle-specific enzyme creatinine kinase. The median level of creatinine kinase activity measured in myotubes from 140 wells after seven days in fusion medium was $1851 \mathrm{U} / \mathrm{g}$ protein $(25$ th-75th centiles 1228 and $2868 \mathrm{U} / \mathrm{g}$ ). For comparison, Blau \& Webster (1981) reported a creatinine kinase activity of $2515 \mathrm{U} / \mathrm{g}$ protein in their primary human skeletal myotube cultures after five days in fusion medium.

In order for skeletal myoblasts to terminally differentiate, they must arrest in $G_{0}$ and withdraw from the cell cycle (Gu et al. 1993). For this to occur, dephosphorylation and inactivation of the $\mathrm{Rb}$ protein is required (Schneider et al. 1994). We showed progressive Rb dephosphorylation during 7 days in FM, as illustrated in Fig. 4, coincidental with cells aligning and fusing, and with the increased CK activity.

\section{Analysis of the IGF system in primary skeletal muscle cultures}

Having successfully isolated and cultured primary human myoblasts which differentiated in low serum medium, we next assessed the IGF system. We found that both myoblasts and myotubes expressed insulin, IGF-I and 


\section{A. Insulin receptor}
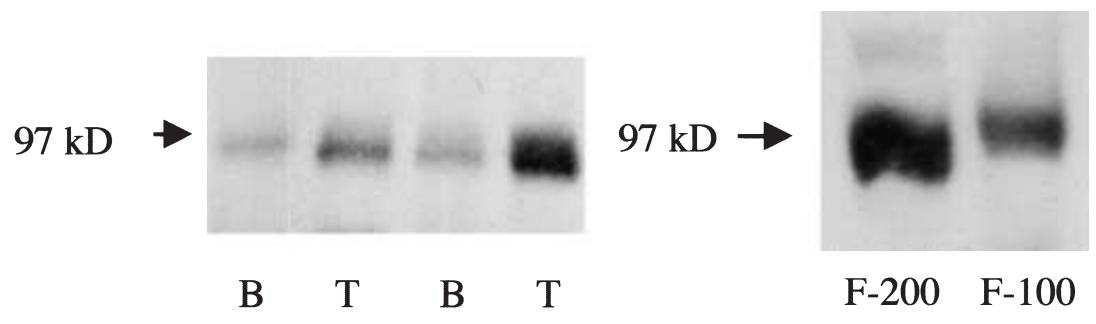

B. IGF-I receptor
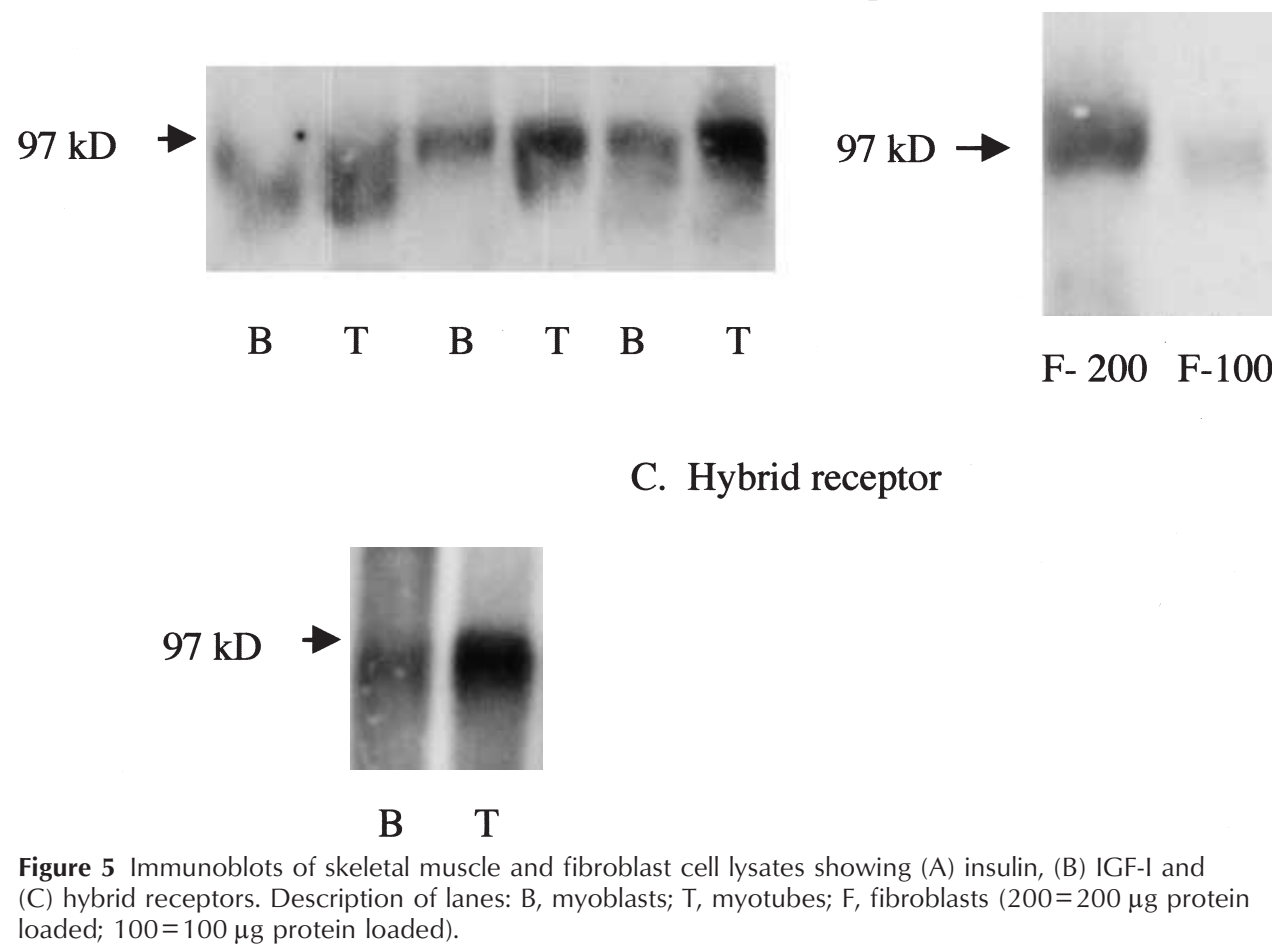

Figure 5 Immunoblots of skeletal muscle and fibroblast cell lysates showing (A) insulin, (B) IGF-I and loaded; $100=100 \mu$ g protein loaded).

insulin-IGF-I-hybrid receptors, as shown in Fig. 5, with the levels of all three receptor types increasing with time in differentiation medium. Optical density measurements comparing myotubes to myoblasts of the same passage and derived from the same subject showed a mean fold increase of 1.73 for the IGF-I receptor, 3.04 for the insulin receptor and 1.35 for the hybrid receptor. Insulin-IGF-I hybrid receptors have a similar affinity for IGF-I as the IGF-I receptor, but a 10-fold lower affinity for insulin than the insulin receptor (Soos et al. 1993), and appear to function like IGF-I receptors (Seely et al. 1995). They are formed in tissues expressing both IGF-I and insulin receptors (Federici et al. 1996, 1998). For positive comparison, fibroblasts also express both IGF-I and insulin receptors (Fig. 5).
Both myoblasts and myotubes produced a wide range of IGFBPs as illustrated in Fig. 6. Surprisingly, this included large amounts of intact IGFBP-3, which has not been shown to be produced by any of the other skeletal muscle cell lines examined to date (McCusker \& Clemmons 1988, 1994, Tollefsen et al. 1989, Florini et al. 1995, Silverman et al. 1995). As the anti-IGFBP-3 antibody does not cross-react with bovine IGFBP-3 in FCS (see lane 6 of the IGFBP-3 immunoblot, Fig. 6A), all IGFBP-3 visualised by immunoblotting represented endogenous production by the cells. This was subsequently confirmed by IGFBP-3 radioimmunoassay of conditioned media. The anti-IGFBP-2 and anti-IGFBP-4 antibodies did crossreact with the binding proteins in the fetal calf serum, making it difficult to assess endogenous production by the 
Ligand blot

\section{IGFBP-3 immunoblot}
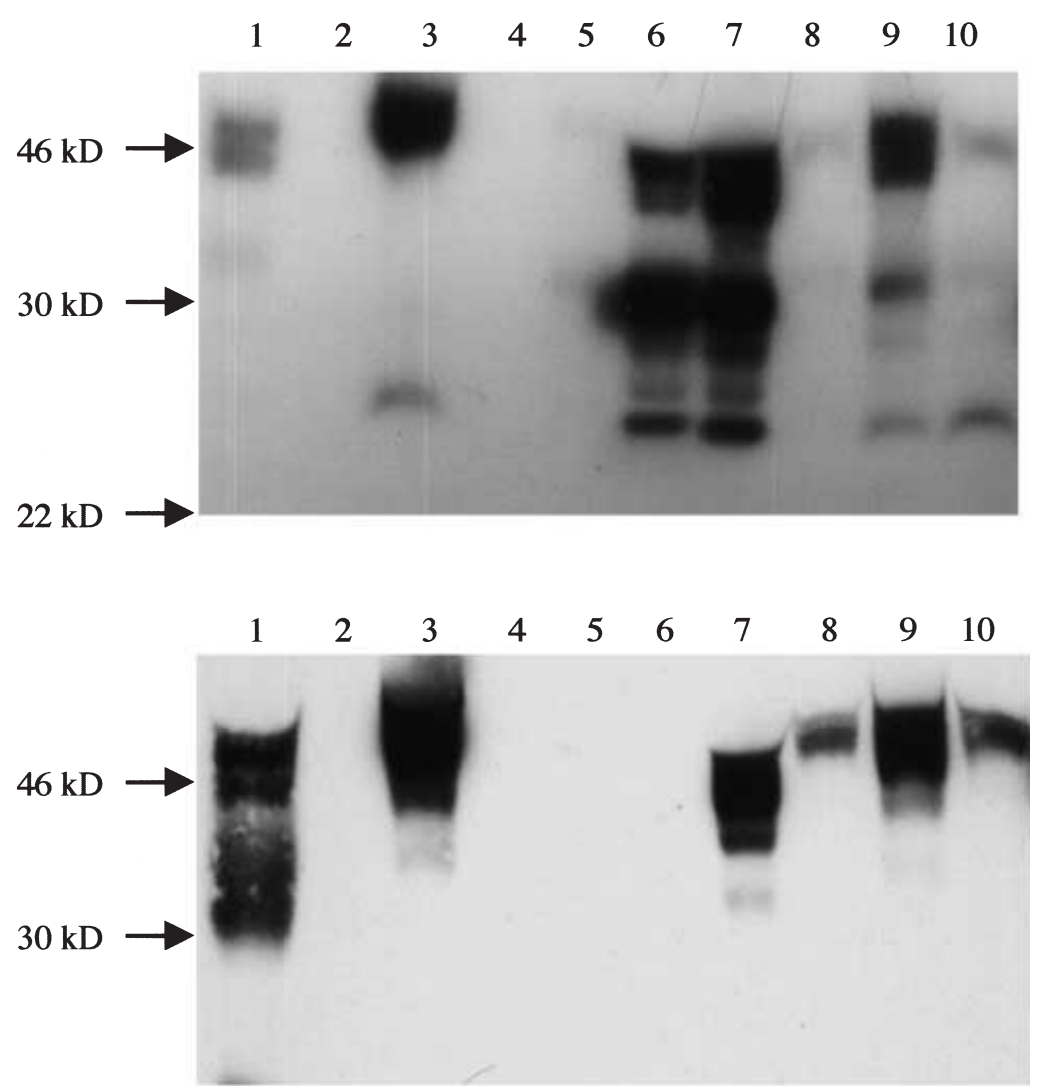

Figure 6 (A) Ligand blot and IGFBP-3 immunoblot of conditioned medium from primary human myoblasts, myotubes and fibroblasts. Lane 1, normal serum pool; lane 2, fibroblast serum-free medium; lane 3, fibroblast conditioned medium; lane 4, skeletal muscle serum-free medium; lane 5, skeletal muscle FM; lane 6, skeletal muscle GM; lane 7, myoblasts in GM (3 days); lane 8, myoblasts in serum-free medium ( 1 day); lane 9, myotubes in FM (3 days); lane 10, myotubes in serum-free medium (1 day). myoblasts in growth medium, although endogenous production of both binding proteins by the differentiated myotubes in fusion medium was shown, as illustrated in Fig. 6B. In contrast to the adult muscle cells, fetal myoblasts produced much less IGFBP-3, IGFBP-2 and a smaller binding protein which was not IGFBP-4 (Fig. 6C). Again, for comparison, the primary human fibroblasts produced a more limited range of IGFBPs, one of which was IGFBP-3 (Fig. 6A).

Radioimmunoassay of myoblast and myotube conditioned media showed no significant endogenous production of IGF-I or IGF-II, above that found in the supplemented media alone (data not shown).

Growth factor effects on myotube protein synthesis and degradation

Having characterised the muscle cells with regard to phenotype and parameters of the IGF system, we wished to determine the functionality of the cells with respect to the physiological end points of protein synthesis and degradation. The dose-response curves showed that sig- nificant anabolic responses to both IGF-I and insulin were seen at feasible physiological tissue concentrations of both peptides (Fig. 7A, B). The muscle cells tended to respond more efficiently to insulin than to IGF-I, suggesting that interference from the IGFBPs could be suppressing IGF-I action. We used $\mathrm{LR}^{3}$ IGF-I, a potent IGF-I analogue which has a very low affinity for the IGFBPs (Conlon et al. 1995), to test the hypothesis that the high levels of endogenous IGFBPs produced by the myotubes were reducing the activity of the exogenous IGF-I. Surprisingly, there were no significant differences in the cells' responses to physiological concentrations of IGF-I compared with $\mathrm{LR}^{3}$ IGF-I. There was considerable variability in the results obtained between experiments, possibly because of the use of cells derived from different subjects which have different degrees of differentiation capacity.

\section{Discussion}

We have established a primary adult human skeletal muscle cell culture system, which we have characterised 
Ligand blot

IGFBP-2

immunoblot

\section{IGFBP-4 immunoblot}

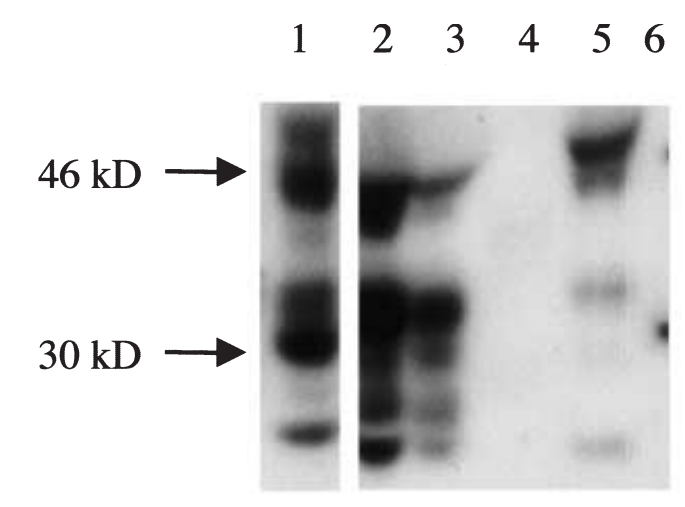

$\begin{array}{llllll}1 & 2 & 3 & 4 & 5 & 6\end{array}$

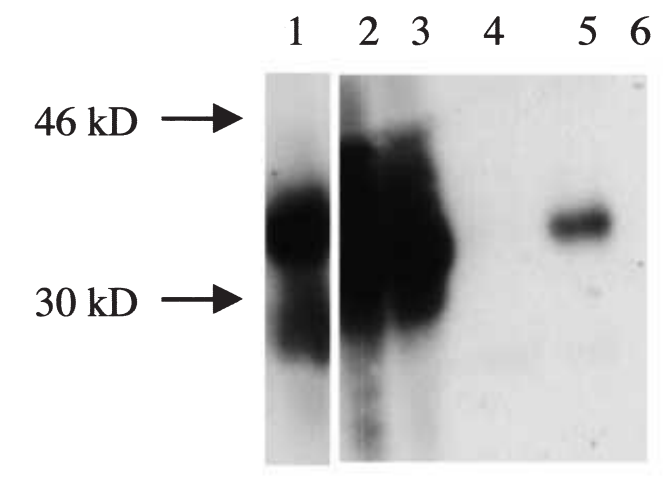

$22 \mathrm{kD}$

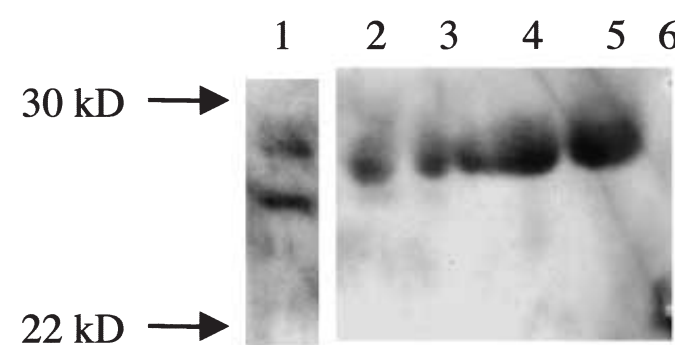

Figure 6 (B) Ligand blot and immunoblots for IGFBP-2 and IGFBP-4 of conditioned medium from primary human myoblasts and myotubes. Lane 1, normal serum pool; lane 2, skeletal muscle GM; lane 3, myoblasts in GM ( 3 days); lane 4, myotubes in FM (2 days); lane 5, myotubes in FM (4 days); lane 6, skeletal muscle FM.

immunocytochemically by desmin and titin staining and biochemically by measuring creatinine kinase activity. Terminal differentiation and myotube formation was associated with $\mathrm{Rb}$ dephosphorylation. FGF stimulated replication of the myoblasts but inhibited differentiation, whilst IGF-I stimulated both replication and differentiation into myotubes. We therefore have access to a clinically relevant model in which to study the pathophysiology of muscle wasting.

With respect to the IGF system, we have shown that the cells express insulin, IGF-I and insulin-IGF-I hybrid receptors, with increased levels of all three types of receptor in myotubes compared with myoblasts. In the BC3H-1, C2 and L6 skeletal muscle cell lines, differentiation is associated with increased insulin but decreased IGF-I receptors levels (Beguino et al. 1985, Brunetti et al. 1989, Rosenthal et al. 1991) although Tollefsen et al. (1989) reported a transient increase in ${ }^{125}$ I-IGF-I binding $72 \mathrm{~h}$ after the induction of differentiation in C2 cells. In primary adult human skeletal muscle cells, Shimizu et al. (1986) found that ${ }^{125} \mathrm{I}$-insulin binding increased on differentiation (being below their limit of detection in 


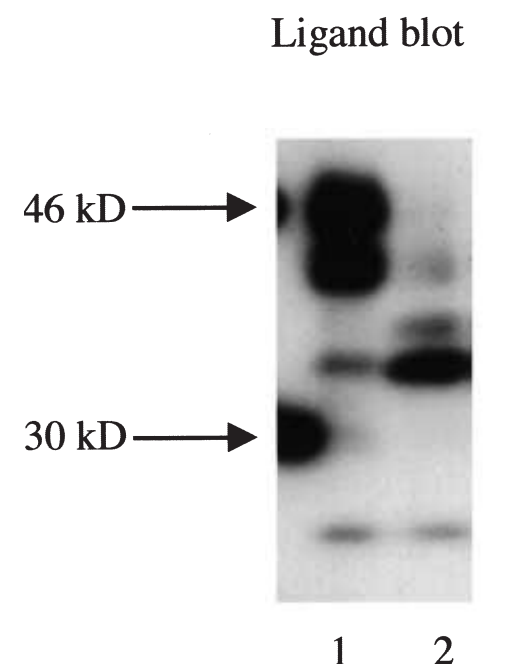

\section{IGFBP-3 immunoblot}

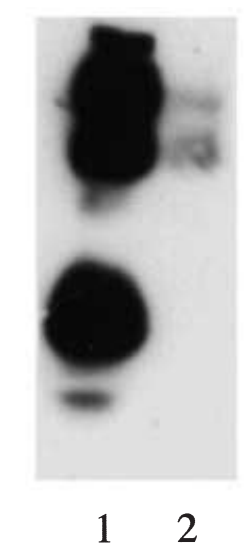

\section{IGFBP-2 immunoblot}

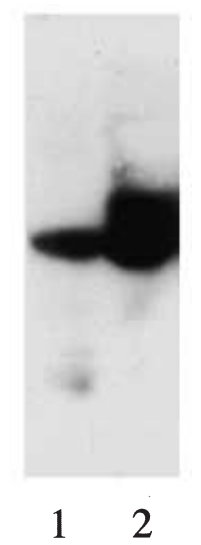

Figure 6 (C) Ligand blot and immunoblots for IGFBP-3 and IGFBP-2 of conditioned medium from human fetal myoblasts. Lane 1, normal serum pool; lane 2, fetal myoblasts in serum-free medium (1 day).

myoblasts), whilst there was no difference in ${ }^{125}$ I-IGF-I binding between myoblasts and myotubes. Our primary cultures produced a wide range of high affinity IGFBPs, including IGFBP-2, -4 and abundant IGFBP-3. The fetal myoblast IGFBP profile included much less IGBP-3, IGFBP-2 and no IGFBP-4. Both profiles contrast with rat L6 muscle cells, which produce IGFBP-4, -5 and -6 (McCusker \& Clemmons 1988, 1994, Silverman et al. 1995), and mouse C2 cells, which only produce IGFBP-5 (Tollefsen et al. 1989, Florini et al. 1995). When fibroblasts are cultured with transforming growth factor- $\beta$, they enter cell cycle arrest. A postulated mechanism is the stimulation of increased production of IGFBP-3 (Kim et al. 1997). The high levels of endogenous IGFBP-3 production by adult human myoblasts could trigger premature cell senescence in vitro, and may explain some of the difficulties experienced by ourselves and others in culturing these cells. It may also inhibit aberrant replication of adult skeletal muscle cells in vivo. Our primary myoblast and myotube cultures did not produce significant amounts of IGF-I or IGF-II peptide.

We found that both insulin and IGF-I had anabolic effects on protein metabolism at physiological concentrations. Insulin was more potent than IGF-I, with lower concentrations required to achieve similar maximal responses. Others have found IGF-I to have more potent protein anabolic effects on myotubes than insulin, the latter being effective only at supraphysiological concentrations when it may have been acting as an IGF-I analogue (Shimizu et al. 1986, Harper et al. 1987, Roe et al. 1989). There are several possible explanations for the differences between our physiological findings and those of others. Our use of recombinant human insulin as opposed to bovine or porcine insulin may explain the relatively high potency of insulin we observed. Alternatively, it may reflect different proportions of IGF-I, insulin and hybrid receptors in the different models. Finally, our data may provide key evidence of the differential effects of insulin and IGF-I which have been postulated, with insulin being a more potent anabolic agent for skeletal muscle protein metabolism, and IGF-I acting predominantly to stimulate muscle cell proliferation and differentiation. Unexpectedly, the equivalence of the responses to IGF-I and $L^{3}$ IGF-I suggested that the wide range of IGFBPs secreted by the cells did not affect the response to exogenous IGF-I with regard to protein anabolism.

There are important differences in the IGF-I receptor status, IGFBP-3 production and the response to insulin of our primary adult human skeletal muscle cells, compared with the results of other investigators using skeletal muscle cell lines and often working with undifferentiated myoblasts rather than differentiated myotubes. This highlights the importance of developing a model which is as physiologically relevant as possible within the constraints of a cell culture system. The IGF system plays a pivotal role in the regulation of skeletal muscle cell cycling and intermediary metabolism in health and disease. We have fully characterised our model with reference to muscle cell status and capacity to differentiate in vitro. We have also assessed the IGF receptor status, binding protein and peptide secretion, and have obtained preliminary results related to protein metabolism indicating both the functionality of the cells and an increased sensitivity to the anabolic effects of insulin compared with IGF-I.

We are now in a position to address more complex questions regarding the pathophysiology of muscle wasting 


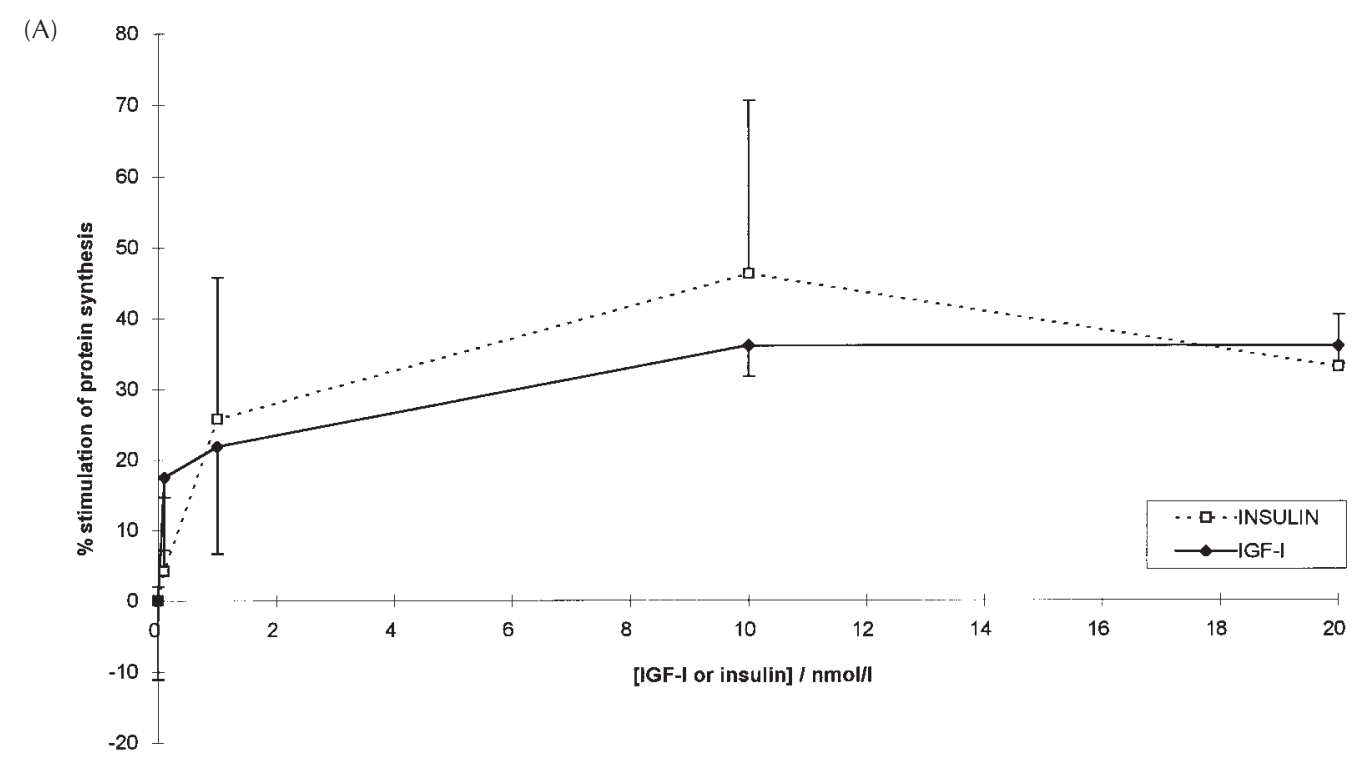

(B)

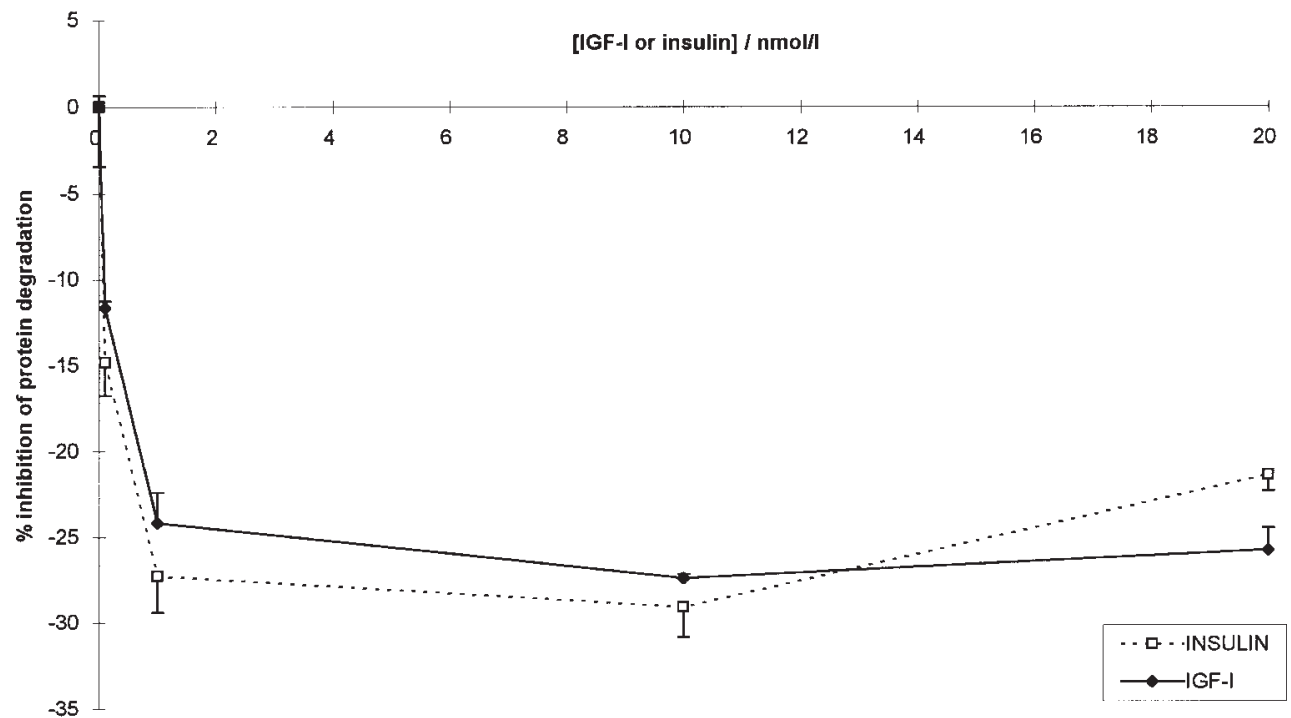

Figure 7 Protein synthesis (A) and degradation (B) of skeletal muscle cells in response to IGF-I ( $\bullet$ ) and insulin ( $\square$ ). Experiments were performed with wells in triplicate (the error bars represent 1 S.D.), and each experiment was repeated at least 3 times.

associated with many chronic severe illnesses. These include interactions between the growth hormone-IGF system, other hormones (such as insulin, cortisol and leptin), and the inflammatory cytokines (tumour necrosis factor- $\alpha$ and interleukins- 1 and -6 ) in the regulation of intermediary metabolism, proliferation, differentiation and apoptosis in skeletal muscle cells. A slight imbalance in any of these processes could influence the equilibrium between muscle maintenance and muscle destruction, resulting in a marked loss of lean body mass. We plan to investigate whether muscle cells grown from patients with cancer maintain a 'cachectic phenotype' in vitro with respect to protein metabolism, analogous to the in vitro insulin resistance of muscle cell cultures derived from patients with Type II diabetes and obesity (Thompson et al. 1996). This would suggest that there are intrinsic abnormalities of the muscle cells in addition to abnormalities in their hormonal and cytokine milieu, which, if identified, could potentially be manipulated and reversed. In the future, such research may lead to the development of novel therapeutic interventions to target the important clinical problem of cachexia, for which at present no effective treatment is available. 


\section{Acknowledgements}

We are grateful to Dr Sandra Jackson and Prof. Douglas Turnbull who described their method of primary muscle cell culture to A LC and allowed her to visit their laboratories. Mr Peter Niven, Consultant Obstetrician and Gynaecologist at St Michael's Hospital, Bristol, and Prof. Derek Alderson, assisted by $\mathrm{Mr}$ Andrew Hollowood, in the Department of Surgery at the Bristol Royal Infirmary, obtained the muscle biopsies. Mr Paul Savage and Mr Paul Newcomb assisted with protein assays and immunocytochemical staining, and Kate Meadows also provided technical support. A L C was funded by a Medical Research Council Clinical Training Fellowship, with additional support from the Neuroendocrinology and Ophthalmology Charitable Trust and the University of Bristol Cancer Research Committee. X L H was funded by Pharmacia and Upjohn, and CEHS was funded by the Special Trustees of the United Bristol Healthcare NHS Trust.

\section{References}

Beguino F, Kahn CR, Moses AC \& Smith RJ 1985 Distinct biologically active receptors for insulin, insulin-like growth factor-I, and insulin-like growth factor-II in cultured skeletal muscle cells. Journal of Biological Chemistry $26015892-15898$.

Blau HM \& Webster C 1981 Isolation and characterisation of human muscle cells. PNAS 78 5623-5627.

Brunetti A, Maddux BA, Wong KY \& Goldfine ID 1989 Muscle cell differentiation is associated with increased insulin receptor biosynthesis and messenger RNA levels. Journal of Clinical Investigation 83 192-198.

Calman KC 1982 Cancer cachexia. British Journal of Hospital Medicine 27 28-9, 33-4.

Conlon MA, Tomas FM, Owens PC, Wallace JC, Howarth GS \& Ballard FJ 1995 Long $\mathrm{R}^{3}$ insulin-like growth factor-I (IGF-I) infusion stimulates organ growth but reduces plasma IGF-I, IGF-II and IGF-binding protein concentrations in the guinea pig. Journal of Endocrinology 146 247-253.

Coulson VJ, Wass JAH, Abdulla AF, Cotterill AM \& Holly JMP 1991 Insulin-like growth factor binding proteins in acromegaly. Growth Regulation 1 119-124.

Cwyfan Hughes SC, Johnson MR, Heinrich G \& Holly JMP 1995 Could the abnormalities in insulin-like growth factors and their binding proteins during pregnancy result in gestational diabetes? Journal of Endocrinology 147 517-524.

DeWys WD, Begg C, Lavin PT, Band PR, Bennett JM, Bertino JR, Cohen MH, Douglass HO, Engstrom PF, Ezdinli EZ, Horton J, Johnson GJ, Moertel CG, Oken MM, Perlia C, Rosenbaum C, Silverstein MN, Skeel RT, Sponzo RW \& Tormey DC 1980 Prognostic effect of weight loss prior to chemotherapy in cancer patients. American Journal of Medicine 69 491-497.

Douglas RG, Gluckman PD, Breier BH, McCall JL, Parry B \& Shaw JHF 1991 Effects of recombinant IGF-I on protein and glucose metabolism in rTNF-infused lambs. American Journal of Physiology 261 E606-E612.

Federici M, Zucaro L, Porzio O, Massoud R, Borboni P, Lauro D \& Sesti G 1996 Increased expression of insulin/insulin-like growth factor-I hybrid receptors in skeletal muscle of non-insulindependent diabetes mellitus subjects. Journal of Clinical Investigation $982887-2893$.

Federici M, Lauro D, D’Adamo M, Giovannone B, Porzio O, Mellozzi M, Tamburrano G, Sbraccia P \& Sesti G 1998 Expression of insulin/IGF-I hybrid receptors is increased in skeletal muscle of patients with chronic primary hyperinsulinaemia. Diabetes $\mathbf{4 7}$ 87-92.

Florini JR, Ewton DZ \& McWade FJ 1995 IGFs, muscle growth, and myogenesis. Diabetes Reviews 3 73-92.

Frost RA, Lang CH \& Gelato MC 1997 Transient exposure of human myoblasts to tumour necrosis factor- $\alpha$ inhibits serum and insulin-like growth factor-I stimulated protein synthesis. Endocrinology 138 4153-4159.

Gu W, Schneider JW, Condorelli G, Kaushal S, Madhavi V \& Nadal-Ginard B 1993 Interaction of myogenic factors and the retinoblastoma protein mediates muscle cell commitment and differentiation. Cell 72 309-324.

Ham RG, St Clair JA, Webster C \& Blau HM 1988 Improved media for normal human muscle satellite cells: serum-free clonal growth and enhanced growth with low serum. In Vitro Cellular and Developmental Biology 24 833-844.

Harper JMM, Soar JB \& Buttery PJ 1987 Changes in protein metabolism of ovine primary muscle cultures on treatment with growth hormone, insulin, insulin-like growth factor-I or epidermal growth factor. Journal of Endocrinology 112 87-96.

Hill DJ, Crace CJ, Strain AJ \& Milner RDG 1986 Regulation of amino acid uptake and deoxyribonucleic acid synthesis in isolated human fetal fibroblasts and myoblasts: effect of human placental lactogen, somatomedin-C, multiplication-stimulating activity, and insulin. Journal of Clinical Endocrinology and Metabolism 62 753-760.

James PL, Stewart CEH \& Rotwein P 1996 Insulin-like growth factor binding protein- 5 modulates muscle differentiation through an insulin-like growth factor-dependent mechanism. Journal of Cell Biology 133 683-694.

Kim H-S, Rosenfeld RG \& Oh Y 1997 Biological roles of insulin-like growth factor binding proteins. Experimental and Molecular Medicine 29 85-96.

Lee PDK, Pivarnik JM, Bukar JG, Muurahainen N, Berry PS, Skolnik PR, Nerad JL, Kudsk KA, Jackson L, Ellis KJ \& Gesundheit N 1996 A randomised, placebo-controlled trial of combined insulin-like growth factor-I and low dose growth hormone for wasting associated with human immunodeficiency virus infection. Journal of Clinical Endocrinology and Metabolism 81 2968-2975.

Lieberman SA, Butterfield GE, Harrison D \& Hoffman AR 1994 Anabolic effects of recombinant insulin-like growth factor-I in cachectic patients with the acquired immunodeficiency syndrome. Journal of Clinical Endocrinology and Metabolism 78 404-410.

Liu J-P, Baker J, Perkins AS, Robertson EJ \& Efstratiadis A 1993 Mice carrying null mutations of the genes encoding insulin-like growth factor-I (IGF-I) and type 1 IGF receptor. Cell 75 59-72.

McCusker RH \& Clemmons DR 1988 Insulin-like growth factor binding protein secretion by muscle cells: effect of cellular differentiation and proliferation. Journal of Cellular Physiology 137 505-512.

McCusker RH \& Clemmons DR 1994 Effects of cytokines on insulin-like growth factor-binding protein secretion by muscle cells in vitro. Endocrinology 134 2095-2102.

Nabel GJ \& Grunfeld C 1996 Calories lost - another mediator of cancer cachexia? Nature Medicine 2 397-398.

Ng E-H, Rock CS, Lazarus DD, Stiano-Coico L, Moldawer LL \& Lowry SF 1992 Insulin-like growth factor-I preserves host lean tissue mass in cancer cachexia. American Journal of Physiology 262 R426-R431.

Roe JA, Harper JMM \& Buttery PJ 1989 Protein metabolism in ovine primary muscle cultures derived from satellite cells - effects of selected peptide hormones and growth factors. Journal of Endocrinology 122 565-571.

Roeder RA, Hossner KL, Sasser RG \& Gunn JM 1988 Regulation of protein turnover by recombinant human insulin-like growth factor in L6 myotube cultures. Hormone and Metabolic Research $\mathbf{2 0}$ 698-700. 
Rosenthal SM, Brunetti A, Brown EJ, Mamula PW \& Goldfine ID 1991 Regulation of insulin-like growth factor-I receptor expression during muscle cell differentiation. Journal of Clinical Investigation 87 1212-1219.

Schneider JW, Gu W, Zhu L, Madhavi V \& Nadal-Ginard B 1994 Reversal of terminal differentiation mediated by $\mathrm{p} 107$ in Rb-/muscle cells. Science 264 1467-1471.

Seely BL, Reichart DR, Takata Y, Yip C \& Olefsky JM 1995 A functional assessment of insulin/insulin-like growth factor-I hybrid receptors. Endocrinology 136 1635-1641.

Shimizu M, Webster C, Morgan DO, Blau HM \& Roth RA 1986 Insulin and insulin-like growth factor receptors and responses in cultured human muscle cells. American Journal of Physiology 251 E611-E615.

Silverman LA, Cheng Z-Q, Hsiao D \& Rosenthal SM 1995 Skeletal muscle cell-derived insulin-like growth factor (IGF) binding proteins inhibit IGF-I-induced myogenesis in rat L6E9 cells. Endocrinology 136 720-726.

Soos MA, Field CE \& Siddle K 1993 Purified hybrid insulin/ insulin-like growth factor-I receptors bind insulin-like growth factor-I, but not insulin, with high affinity. Biochemical Journal 290 419-426.

Stewart CEH \& Rotwein P 1996 Growth, differentiation, and survival: multiple physiological functions for insulin-like growth factors. Physiological Reviews 76 1005-1026.
Thompson DB, Pratley R \& Ossowski V 1996 Human primary myoblast cell cultures from non-diabetic insulin-resistant subjects retain defects in insulin action. Journal of Clinical Investigation $\mathbf{9 8}$ 2346-2350.

Tollefsen SE, Lajara R, McCusker RH, Clemmons DR \& Rotwein P 1989 Insulin-like growth factor (IGF) in muscle development. Journal of Biological Chemistry 264 13810-13817.

Tomas FM, Chandler CS, Coyle P, Bourgeois CS, Burgoyne JL \& Rofe AM 1994 Effects of insulin and insulin-like growth factors on protein and energy metabolism in tumour-bearing rats. Biochemical Journal 301 769-775.

van der Ven PF, Schaart G, Jap PHK, Sengers RCA, Stadhouders AM \& Ramackers FC 1992 Differentiation of human skeletal muscle cells in culture: maturation as indicated by titin and desmin striation. Cell and Tissue Research 270 189-198.

Wilmore DW 1991 Catabolic illness. New England Journal of Medicine 325 695-702.

Wolf RF, Pearlstone DB, Newman E, Heslin MJ, Gonenne A, Burt M \& Brennan MF 1992 Growth hormone and insulin reverse net whole body and skeletal muscle protein catabolism in cancer patients. Annals of Surgery 216 280-290.

Received 19 May 2000

Accepted 23 August 2000 